\title{
Innovation and Entrepreneurship Education Ways of Agricultural Mechanization Majors
}

\author{
Junzheng Wang \\ College of engineering and technology \\ Jilin Agricultural University \\ Graduate School of Jilin Agricultural University \\ Changchun, China
}

\author{
Yahong Liang* \\ College of engineering and technology \\ Jilin Agricultural University \\ Graduate School of Jilin Agricultural University \\ Changchun, China \\ *Corresponding Author
}

\author{
Jingli Wang \\ College of engineering and technology \\ Jilin Agricultural University \\ Graduate School of Jilin Agricultural University \\ Changchun, China
}

\begin{abstract}
Long-term Education Reform and Development Plan" (2010-2020) calls for strengthening college students innovation and entrepreneurship education and employment guidance services. With the innovative economic model, the demand for innovative entrepreneurial talent is rising. However, the cultivation of innovative entrepreneurial talent can not be separated from the entrepreneurial education. This paper aims to study the ways of innovation and entrepreneurship education that includes government policies, the formation of a wide range of business mentor team, building a systematic curriculum, creating practice teaching models, establishing and improving entrepreneurship education guarantee system and so on.
\end{abstract}

Keywords-agricultural mechanization; innovation and entrepreneurship education; ways

\section{INTRODUCTION}

Employment is Basic thing; entrepreneurship is a source of employment."Proposal thirteenth five-year plan of the CPC Central Committee on National Economic and Social Development" formulates that employment and entrepreneurship development is an important content sharing through party-eighth the Fifth Plenary Session[1].Marx's theory of "people's all-round free development" is of great significance to guiding the innovation and entrepreneurship education in Colleges and universities, Entrepreneurship Education in Colleges and universities aims to cultivate the overall quality and the free development of socialist entrepreneurs. However, the traditional teaching content on the courses of agricultural mechanization specialty explains the mechanical foundation and professional knowledge-based, which focus on mastering the use of the structure and other basic principles of content and agricultural machinery[2]. Therefore, this paper carries on a series of research on the

Subject name: Agricultural Entrepreneurship Education System University Students

Study ID: Education science of Jilin Province [2015] No. 118;

Subject name:Students Innovative Talents Training Model Common Agricultural Colleges and Universities Research Study ID: GH150216. innovation and entrepreneurship education of agricultural mechanization specialty students, and puts forward the following recommendations for improvement.

\section{A PERFECT POLICY OF UNDERGRADUATE INNOVATION AND ENTREPRENEURSHIP}

China is still a large agricultural country that is particularly important to promote the development of agricultural economy with the development of agricultural mechanization and the use of scientific and technological. The government should introduce appropriate policies to support agricultural mechanization encourage students to start their own business for students who are interested in entrepreneurship. In the "Proposal thirteenth five-year plan of the CPC Central Committee on National Economic and Social Development" expressly provides to improve business support policies, encourage entrepreneurship with employment and establish of business service platform for everyone. So governments at all levels should implement the relevant policies of the CPC Central Committee, introduce to encourage innovation and entrepreneurship students policy specifically encouraged by the Communist Youth League team composed of structures "Youth Innovation Park" and other related platforms. It is providing project development, business guide, financial services, follow-up assistance and other services for the entrepreneurship of college students.

\section{THE UNIVERSITY SETTING UP A TEAM OF INNOVATION AND ENTREPRENEURSHIP MENTOR}

Universities should introduce the high-level personnel and take voluntary principles to encourage teachers to compete as a full-time instructor for mechanization students with innovation and entrepreneurship in the agricultural mechanization professional teaching process. Universities give some kind of material and spiritual rewards for these teachers, and create a 
good environment for Teaching Entrepreneurship. In addition, schools should also be introduced in the field of agricultural mechanization relevant companies technical staff, hiring technical staff as an part-time instructor for innovation and entrepreneurship, They have a strong practical ability to mechanical operation, the most close to the market demand for mechanization skills for students of innovation and a more practical guidance for innovation and entrepreneurship. The mentor team for mechanization students' innovation and entrepreneurship is constituted of full-time instructors who are good at theory and part-time instructors with practical skills.

\section{BUILDING SYSTEMIC INNOVATION AND ENTREPRENEURSHIP CURRICULUM SYSTEM}

\section{A. Improving Innovation and Entrepreneurship Curriculum}

Universities should offer innovative entrepreneurship education curriculum, professional courses and elective courses. These three courses take public required courses, public elective courses, professional courses and professional elective courses and other different forms. They were taken to a different credit system to allow students to choose their own courses of interest, as long as they complete the regulated credits.

\section{B. Improving Innovation and Entrepreneurship Courses}

In order to cultivate students' ability of innovation and entrepreneurship, stimulate students' innovation and entrepreneurship awareness, the curriculum is formulated, also students taking part in learning activities appropriate courses. For example, schools should be set up training seminars for mechanization students with entrepreneurship, carry out the competitions of innovation and entrepreneurship and visit to the mechanized enterprises and other activities.

\section{Improving the Practice Course of Innovation and Entrepreneurship}

Practice is the sole criterion for testing truth, in order to learn the theoretical knowledge into practice on the course being used to guide practice. Universities provide students with relevant practical courses can be divided into practice and simulate real practice two kinds. To this end, the school should establish a simulation laboratory for college students in mechanical specialty, or the establishment of "College Students' entrepreneurial park" and other simulation practice base in the school, providing help for the preparation of students. In addition, we should also realize the schoolenterprise cooperation, mechanization professional preparation of students to entrepreneurial opportunities for business practices, studying business management processes, technical operations and other skills.

\section{Improving the Innovation and Entrepreneurship Competition}

Colleges' innovation and entrepreneurship education originated in the 20th century the "Challenge Cup" Business Plan Competition [3].Schools should provide students with the opportunity to participate in the corresponding race, by participating in "College Challenge Cup" and other innovative entrepreneurship competition with other university teachers and students to communicate and understand the industry forefront of innovation and entrepreneurship information. In addition, it can promote the comprehensive development of students' creativity and their own qualities.

\section{ESTABLISH A SOUND SECURITY SYSTEM INNOVATION AND ENTREPRENEURSHIP EDUCATION}

\section{A. Creating a Favorable Environment for Innovation and Entrepreneurship Education}

Government departments should further deepen reform of the system of administrative examination and approval system and commercial matters, reducing market access barriers. It should increase entrepreneurship propaganda and create conditions conducive to entrepreneurship, tolerance of failure of the social atmosphere, foster innovation and entrepreneurial culture. So the mechanization of agriculture professional and entrepreneurial students are given free rent, free of tax incentives and other related substances. So entrepreneurship to create jobs, alleviate the difficult issues such as employment of university students, promoting the formation of new dynamic economic and social development, thereby adjusting the economic structure, promote the formation of innovation and entrepreneurship development strategy.

\section{B. Broadening the Financing Channels of Innovation and Entrepreneurship Education}

The economic base determines the superstructure, which is a major financial difficulties troubled innovation and entrepreneurship education success. To this end, first, the government joint banking institutions such as the development of business guarantee loans, focusing on solving the problem of venture financing. Increasing tax cuts to reduce costs, and effectively reducing the tax burden on entrepreneurs. Second, colleges and universities should play their own personnel, adhere to the open policy, the initiative to establish cooperative links with the mechanization of enterprises, providing agricultural mechanization talent, to attract business investment, and can take the "integration of industry" and other forms of enterprises to attract capital. Third, colleges and universities should take the initiative to set up the "outstanding Alumni Association" that can encourage outstanding alumni to the school to carry out the project investment.

\section{CONCLUSION}

Agricultural Mechanization Students innovation and entrepreneurship education is to adapt to development of the situation in today's age needs, is the need to improve our human resources overall quality, is the need to promote China's economic development situation, the need to build national innovation Venture System, is the cultivation of university create entrepreneurial talents need and the need is to train students' innovative entrepreneurial ability. 


\section{REFERENCES}

[1] http://edu.youth.cn/2015/1215/3190117.shtml

[2] Zhu Dequan, Zhang Niansheng, Wang Shuo. Study on the cultivation system of innovative ability of agricultural mechanization major $[\mathrm{J}]$. Anhui agricultural Bulletin (upper semi monthly), 2011,21:165-166.

[3] Fan Peng.Research of ntrepreneurship education on undergraduate college[D]. Huazhong Agricultural University, 2014. 